\title{
Claiming a Great Ancient Imperial Past as an Identity Element of a Small Modern Nation
}

\author{
The Case of Lithuania
}

\author{
Zenonas Norkus and Aelita Ambrulevičiūtè
}

\begin{abstract}
Lithuanians are a typical East European modern nation, created by the Lithuanian nationalist movement which emerged in the late nineteenth century. Modern Lithuanian identity is ethnolinguistic, resembling national identities of other Baltic countries. Its distinctive feature is the narrative appropriation of the history of the Grand Duchy of Lithuania, which was a multi-ethnic, multi-confessional and multi-cultural empire which in 1569 merged with Poland in the Polish-Lithuanian Commonwealth. Reminiscences of this great imperial past became an important source of inspiration for Lithuanian foreign policy after the accession of the country to the European Union in 2004. The makers of this policy conceived as Lithuania's mission to 'bring back' to European civilization all former lands of ancient Lithuania. They used the Lithuanian presidency of the Council of the EU in 2013 to materialise these ideas, which became an important contribution to the outbreak of the Ukrainian crisis. The contribution closes with the discussion of other impending crises related to the legacy of the Grand Duchy of Lithuania.
\end{abstract}

\section{Introduction}

The aim of this paper is to contribute to the exploration of the role of national stereotypes and cultural identities to the outbreak of the recent European crises, by providing a case study of the influence of some distinctive features of modern Lithuanian national identity on the foreign policy of Lithuania as a member state of European Union (EU) since 2004. ${ }^{1}$ The list of recent European crises includes the unresolved Ukrainian crisis, which broke out in 2014

1 This project has received funding from European Social Fund (project number o9.3·3-LMT-K712-01-0oo6) under grant agreement with the Research Council of Lithuania (LMTLT).

(C) ZENONAS NORKUS AND AELITA AMBRULEVIČIŪTĖ, 2021 | DOI:10.1163/9789004436107_004 
in the wake of the Maidan revolution. The chain of events leading to these outcomes started in the 2013, when Lithuania became the first Baltic State to take the Presidency of the Council of the European Union in the second half of that year.

We do not attempt to estimate the exact share of Lithuania's responsibility for the emergence and ambiguous outcomes of this crisis. We will focus on only one specific question, which is relevant for this task: how to explain Lithuania's zeal on behalf of an Eastern expansion of the EU and NATO and its intransigence against Russia, which is out of proportion with the size of its territory, population and economy? Even a glimpse at the map to find out Lithuania's geographical location is sufficient to get the idea that a tough stance in relations with Russia does not promise much in terms of economic rationality. However, Lithuania is no less an ardent supporter of the 'Europeanisation' and 'Westernisation' of Belarus, Moldova, Georgia than that of Ukraine. It consciously takes the self-inflicted costs of this policy, aiming at minimisation of trade with Russia.

This paper provides 'culturalist' or 'identity-theoretic' arguments, explaining post-communist Lithuania's permanent challenging of Russia with specific features of its national identity, shaped by narratives of its ancient imperial grandeur. We will start with recalling some basic facts about the political history of Lithuania in the very brief first section and by introducing our working concepts. The second section zooms in on the contribution of the influential Lithuanian intellectual and opinion-maker Gintautas Beresnevičius, who made the most influential contribution to the elaboration and dissemination of Lithuania's 'imperialist' mythology. The third section provides an account of the influence of reminiscences of Lithuania's medieval imperial greatness on Lithuania's Eastern foreign policy making after its accession to the EU and NATO in 2004. The concluding section discusses the ambiguous achievements and predicaments of this policy, related to similar claims of Lithuania's more powerful neighbours.

Modern Lithuania is a typical East-European modern nation, created by the Lithuanian nationalist movement which emerged in the late nineteenth century. ${ }^{2}$ Its leaders used the historical opportunity provided by the defeat of East

2 See Hroch (1985). 
European empires in World War I to establish an independent Lithuanian national state in 1918. After two decades of independent development, the Republic of Lithuania was occupied and then annexed by the Soviet Union in 1940, re-emerging as independent state after the dissolution of the occupier state. Actually, the breakup of the UsSR was initiated by Lithuania, which proclaimed its independence on 11 March 1990, and was followed by most former Soviet republics only after the failure of the August coup in 1991.

Lithuania's pioneering role in the dissolution of the USSR provides impressive testimony to the national commitment of modern Lithuanians. In fact, national identity is the most important type of modern identity. "National identities do what collective identities do in general: they are stories that combine a series of events in texts, songs and images which some people recognize as being part of their particular we, i.e. as a collective identity". ${ }^{3}$ What is particular about national identities as specifically modern identities is that these "identity constructions have succeeded in imposing themselves as a hegemonic identity in a territorially bounded political community." ${ }^{4}$ They provide these communities with vertical bonds of solidarity, across different social strata.

National communities may broadly vary in terms of the size of territory and population. Together with the bearers of hegemonic identities in neighbouring Baltic countries (Estonia, Latvia, Finland), modern Lithuanians represent the type of small modern nations. In comparison with these neighbours, Lithuanian national identity stands out by the prominent role of narratives about the medieval polity known as the Grand Duchy of Lithuania (GDL), perceived by modern Lithuanians as their precursor state. Young Estonians, Finns and Latvians read in their school textbooks stories about the Middle Ages, describing their ancestors as victims of foreign conquest and rule by more formidable neighbours. For Estonians and Latvians, these neighbours were Danes and Germans, and for Finns the Swedes. Most up-to-date versions of these textbooks contain the provision that this conquest pre-empted a much worse conquest by Russians and also enabled native peoples to join Western civilisation. Very differently, Lithuanian pupils learn history by reading stories describing them as the progeny of conquerors who created a huge medieval empire. ${ }^{5}$ We will argue that the reminiscences of this imperial greatness is an important driving force behind Lithuania's eastward foreign policies.

3 Eder (2009), p. $43^{2}$.

4 Eder (2009), p. 432.

5 For authoritative accounts representing the contemporary Lithuanian view of the history of GDL see Baronas et al. (2011); Gudavičius (1999); Kiaupa et al. (200o); Kiaupienė, Petrauskas (2009); Rowell (1994). See also Norkus (2018). 

Lithuania's Neo-Imperialist Foreign Policy Doctrine

In the early 2ooos the work of the influential Lithuanian public intellectual Gintaras Beresnevičius (1961-20o6) became an important source of inspiration for the forging of Lithuanian foreign policy. He was a leading Lithuanian scholar in religion studies, specialising in pre-Christian Baltic mythology - a kind of Lithuanian Mircea Eliade. These are titles in English of some of Beresnevičius's works in religious studies: Heavens. The Idea of Post-Human Life in the Ancient Lithuanian Worldview (1990); Religious Reforms of Balts (1995); Cosmos and Sacral Places in the Religions of Lithuanians and Prussians (1998); Palemonas Node. the Peripheric Content of the Palemonas Tale (2003); Lithuanian Religion and Mythology (2004). He also published novels, poems, and numerous essays. In 2003, he published the book The Making of Empire (Imperijos darymas). ${ }^{6}$ It was an exploratory study of the prospects of Lithuanian foreign policy, published on the eve of Lithuania joining the EU and NATO in the following year. It was commissioned by the Institute of International Relations and Political Science of Vilnius university, which is reputed to be the 'think tank' of the Lithuanian government.

In this study, Beresnevičius advanced a grandiose vision of the mission of Lithuania after joining the EU and NATO. He suggested to use these memberships as an opportunity for "the making of empire", which is the title of his most famous book. ${ }^{7}$ According to Beresnevičius, this means becoming the bridgehead and vanguard of the eastward extension of the EU and NATO. More specifically, it means spearheading the export of democracy to the former republics of the USSR. "We have an opportunity to use the current situation to lay the foundation for our own geopolitical bloc, tectonic bloc, to

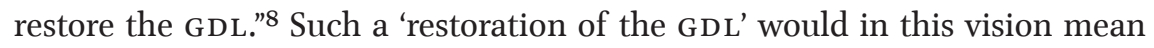
the creation of some kind of community of nations including not only states in the former territory of the GDL, but also Transcaucasian and even Central Asian countries, something distantly similar to the British Commonwealth of Nations. "We must enter the EU as a democratic empire, by acting in the spaces which possibly will exceed the territory of the EU itself."

Interestingly, the ancient Lithuanian empire was for Beresnevičius not synonymous with the GDL. He adopted parahistorical theories about an active

6 Beresnevičius (2003a).

7 Beresnevičius (2003a).

8 Beresnevičius (2003a), p. 72. All translations by the authors.

9 Beresnevičius (2003a), p. 7 . 
participation of Baltic tribes in the events of 'Barbarian invasions' or the Völkerwanderung during the period 200-6oo A.D., with the collapse of the Western Roman empire as its most important world-historic outcome. ${ }^{10}$ Writing about ancient times he therefore avoids exact dates and prefers general descriptions, which anachronistically mix the events of the third to sixth centuries with those of the thirteenth to fifteenth centuries. In this way, the emergence of the GDL in the thirteenth and fourteenth centuries is represented as the continuation of imperialist activities by the ethnic ancestors of modern Lithuanians during much earlier times. The following quotation may serve to provide an impression of his mesmerising style.

As the tillers always prevail in numbers, the ruling military nobility takes over their language and culture. If this culture is higher, than the higher culture is adopted, if it is lower, then the lower one is. This is what adaptation means. Lithuanians in this respect behaved in exactly the same way as Norman, Gothic or Langobard dukes did. The difference is that they did not disappear, and they did not disappear because they had a unitary ethnic base, Ethnic Lithuania. If this ethnic base would have moved and arrived say to the lower Dnieper or the lower Volga, they would have disappeared ruling somewhere in Kiev or Sarai on the very summit of their domination. Barbarians who have created Europe did finish their histories in such a way. Lithuanians are unique among barbarians who have participated in the migration of peoples in that they preserved their ties with their old fatherland, and therefore this base has survived. ${ }^{11}$

Surviving in their ancient motherland, Beresnevičius contends, Lithuanians remain the same 'perennial Barbarians' from Völkerwanderung times, which are flourishing only when they act according to their perennial imperial drive, being in their own element. Otherwise they perform acts of self-destruction or engage in criminal activities.

Obviously, such essentialist views have nothing in common with scholarly historical or social scientific analysis. However, Beresnevičius' aim is not to provide academic analysis, but to construct a political myth useful for the contemporary power elite of Lithuania in inspiring its citizens to bear the costs of playing the self-assumed role of vanguard of the Eastern expansion of NATO and the EU. In this role, Lithuania would challenge semi-authoritarian Russia.

10 See Statkutè de Rosales (2004), Gedgaudas (1972).

11 Beresnevičius (2003a), p. nlf. 
In the struggle for this goal, Lithuania should work to decrease the geopolitical space which Moscow still tries to keep under its control.

Europe needs our empire, I think the US needs it too - both powers will not need much time to understand this, and all their actions show that they understand. [...] With our help Ukraine and Belarus should culturally and politically immediately be integrated into Central Europe; this is the space of GDL; Armenia, Azerbaijan, Georgia should be considered in exactly the same way. The next sphere is Central Asia, going right up to China. ${ }^{12}$

How (if at all) can this breath-taking vision be implemented practically? Are the resources of small Lithuania not too meagre? Obviously it cannot be implemented by the methods used by ancient Lithuanian rulers. Practical measures proposed by Beresnevičius include, firstly, the creation of a Lithuanian Legion. This would be an elite military task force, which the military command of NATO would be free to employ in all 'hot spots' of the world. The beneficial side-effect of this measure would be the reduction of criminality in Lithuania. The legion "would absorb all potential criminals, depressed persons, addicts. If we have the Lithuanian legion, [...] then the dream of each adolescent schoolboy will not be to become a car thief or drug dealer, but a soldier". ${ }^{13}$ Secondly, Beresnevičius proposed to establish a programme of stipends and grants for students, scholars and intellectuals from Belarus, Ukraine and other prospective members of the restored GDL.

While all this costs money, the costs would be comparatively small. All this is an investment into cultivating our 'agents' in these countries. All states which have such political interests and perceive them similarly, have similar foundations and fellowship programs. They shape their image from the inside through future journalists, programmers, statesmen. ${ }^{14}$

In competition with other powers eager to grow their own 'fifth column' in the former Soviet republics, Lithuania has two advantages. As a small state, it cannot be perceived as a real threat (even by Russia). It also can exploit the memories of common victimhood, shared with populations of most Soviet republics.

\footnotetext{
12 Beresnevičius (2003a), p. 75 .

13 Beresnevičius (2003a), p. 56.

14 Beresnevičius (2003a), p. 16f.
} 
The third proposal is at the same time the cheapest and the most difficult to implement. This is the change of the perception of emigration from Lithuania. Since the restoration of independence, Lithuania's population decreased from 3.7 million in 1989 to 3.5 million according to the general census in 2001, i.e. at the time when Beresnevičius announced his programme for the restoration of the GDL. This decrease was also caused by mortality rates exceeding birth rates since 1994, but emigration is the major cause. It continued also after Lithuania's accession to the EU in 2004, sinking to 2.8 million in 2018. These demographic changes became a matter of common concern in Lithuania around the year 2000. Advancing his programme of the "restoration of the GDL", Beresnevičius made the bold proposal to re-frame the present emigration as a continuation of a perennial trend since Völkerwanderung times, driving Lithuanian imperial expansion. Present-day Lithuanian emigrants should be considered as 'colonists', spearheading the latest wave of Lithuania's imperialist expansion. Emigrant quarters in the cities of the advanced Western countries are equivalents of the military colonies planted by the ancient Lithuanian rulers in Slavic lands.

We should not perceive emigration as a catastrophe, because the contemporary world context and internal movement within the European Union universalize these problems. [...]. We should not impose on emigrants the self-consciousness of a 'lost generation' or a 'broken thread', because in this way we infuse into our diaspora the complex - to break away and not come back. The Jewish diaspora can set the example for our own diaspora, as far as Israel would not be a superpower with its territory. ${ }^{15}$

The ultimate aim of this new Lithuanian imperialism should be Lithuania becoming the leading power in the 'new Europe' - formerly communist East European countries, famously so designated by the US Secretary of Defense Donald Rumsfeld, who praised them for their greater willingness to participate in the American invasion of Iraq in 2003 as compared to older NATO members like Germany and France. According to Beresnevičius' diagnosis, "old Europe"16 is facing its "autumn", ${ }^{17}$ displaying signs of weakness like "cowardly hearts, lack of education, economic hazards, cracks in genofond, exaggerated political correctness which civilisationally supresses ripening of new ideas". 18 The mission

\footnotetext{
15 Beresnevičius (2003a), p. 17.

16 Beresnevičius (2003a), p. 21, 67f.,

17 Beresnevičius (2003a), p 31, 55, 68,

18 Beresnevičius (2003a), p.31.
} 
of "new Europe"19 led by Lithuania, is to help to make this autumn a "calm golden autumn" 20 , providing (in the alliance with the US) "the perimeter of security"21 for a hundred years or more.

Perhaps for the first time during a very long time we are on the side of the powerful, becoming part of the largest power concentration. This is a historical chance which we have to use; it looks like in Star Wars: the Force is with you. I am not speaking tongue-in-cheek here. If the world is twosided, it is not bad to be on the proper side and to join it at the right time. ${ }^{22}$

Beresnevičius even plays with the idea of the imminent rise (or rather restoration) of Lithuanian civilisation, discussing in detail its central symbols - the Rüpintojèlis (Pensive Christ) and the Vytis, an armour-clad knight on the back of a white horse, holding sword and shield. The Vytis (part of the the Lithuanian coat of arms) stands for Lithuania as empire, originally representing a pagan war god. Rüpintojèlis is the most popular figure in the Lithuanian religious folk woodwork. According to Beresnevičius, it stands for the promise of the original Lithuanian civilisation to solve the ecological problems of the modern world. This civilisation will be based on the use of renewable resources (wood, water, earth instead of stone, metal, oil), on the spoken word and on meditation.

In the Footsteps of the Grand Duchy: Lithuania's Eastern Foreign Policy after the Accession to the EU and NATO

Beresnevičius' dream of the creation or restoration of the Lithuanian civilisation may appeal only to a handful supporters of the neo-pagan movement Romuva, a religious New Age movement reviving the ancient religious practices of the Baltic tribes before their christianisation. ${ }^{23}$ However, his ideas about Lithuania's membership of the EU and NATO as the chance for 'making empire' in the former territories of the GDL were embraced by an informal group of entrepreneurs, media moguls and high-ranking state officials of Lithuania known as valstybininkai (statesmen) among political observers. ${ }^{24}$ They

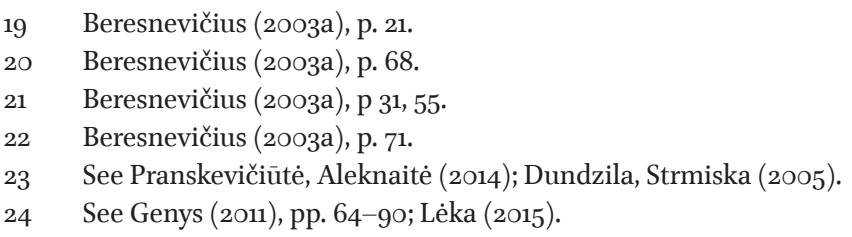


were the driving force behind the removal of President Rolandas Paksas by impeachment in 2003-2004 after his unexpected victory against American Lithuanian Valdas Adamkus, who served his first term as President in 19982003 and did run for second term in 2003. ${ }^{25}$ Ousting Paksas, they remained in firm control of Lithuania's internal and foreign policy during the short period under acting President Artūras Paulauskas in April-July 2004 and during the second term of Adamkus in 2004-2009, who was re-elected after all in the new election following the removal of Paksas.

Among the valstybininkai, the two most influential figures were Raimundas Lopata (born 1965), who from 1998 to 2009 served as the director of the prestigious Institute of International Relations and Political Science at Vilnius University, and Albinas Januška (born 196o), described as the 'grey eminence' of Lithuanian politics in the confidential reports of Western diplomats in Vilnius, published by Wikileaks. ${ }^{26}$ Between 1993 and 2008 he served in various top positions in the Ministry of Foreign Affairs of Lithuania and became chief advisor for Adamkus. Together with another influential member of the valstybininkai group, Mečys Laurinkus, who was the Head of the Lithuanian secret service, he masterminded the removal of Paksas via impeachment. At the same time, the Institute of International Relations and Political Science under Lopata established itself as the main 'think tank' for the Lithuanian government.

Arguably, Januška and Lopata were the most influential makers of Lithuanian foreign policy from 2004 to 2009, forging the doctrine of Lithuania as the "regional centre" or "regional power". ${ }^{27}$ In May 200o, during the meeting of the ministers of foreign affairs of Albania, Bulgaria, Croatia, Estonia, Latvia, Lithuania, Macedonia, Romania, Slovakia and Slovenia a group of countries applying for membership in NATO was established. After it was joined by Croatia, it was called "Vilnius 10" group. At this time, Lithuanian politicians felt that theirs was a very important country. They were eager to make permanent their self-assumed and self-perceived role as leader of the New (post-Communist) West - even if there were few (if any) neighbouring countries which recognised Lithuania in such a role. This aim was proclaimed by the acting President Paulauskas in 2004, ${ }^{28}$ and then reasserted on numerous occasions by Adamkus:

\footnotetext{
25 See Norkus (2012), pp. 296-324.

26 See Lèka (2015).

27 For surveys of Lithuania's foreign policy after accession to the EU see Baubinaite (2011); Jonavičius (2006); Kojala, Ivanauskas (2014); Lopata, Statkus (2005); Paulauskas (2005); Statkus, Paulauskas et al. (2006).

28 See Paulauskas (2004).
} 
Lithuania can and must be a centre of regional gravity. That should be our strategic orientation. This is ambitious, but we have historic, geographic and political preconditions to succeed. [...] I see Vilnius as a natural centre of the region, where political initiatives are being born and implemented. ${ }^{29}$

The authors of this doctrine hoped to compensate for Lithuania's rather modest resources by the country's special relations with the United States, profiling it as the most trustworthy state in the new Europe, deserving the role of the leading operator of US resources in the promotion of democracy in the former republics of the USSR. For this role, Lithuania's status as a former Soviet republic would not be a liability but an asset, providing first-hand knowledge of local conditions and the trust of local elites thanks to a common past and similar cultural background. The country's small size and apparent weakness would make its activities less conspicuous and suspicious both for opponents of the Western infiltration in these countries and for sceptics about the eastward enlargement of NATO and the EU in Western European countries.

Actually, there were two other former Soviet republics which became part of the "new Europe" in 2004: Estonia and Latvia. However, according to the assessment by Lithuania's valstybininkai, it had a crucial competitive advantage in the rivalry for the role of top operator and coordinator of the eastward promotion of democracy: the legacy of the GDL, which provided a special relationship with Belarus and Ukraine, the most important targets for the promotion of democracy. ${ }^{30}$ The Lithuanian elites were strengthened in their belief in the importance of shared memories of the Grand Duchy by the events of the Orange Revolution in Ukraine. Between November 2004 and January 2005, the Orange Revolution was staged by supporters of the pro-Western presidential candidate Viktor Yushchenko, who refused to recognize his defeat, claiming that the vote was rigged. Together with Poland's President Aleksander Kwaśniewski, Adamkus was invited to mediate, playing an important role in persuading Yushchenko's opponent Viktor Yanukovich to yield and to accept a repeat of the run-off vote, which brought victory to Yushchenko.

Soon Lopata could be delighted to see that Adamkus was so fascinated with the claimed role of Lithuania as regional power that he "started to identify himself with former rulers of Lithuania as their direct heir". ${ }^{31}$ During the 2009 millennial celebration of the first recorded mention of the name of Lithuania,

29 Adamkus (2004b). See also Adamkus (2004a); Adamkus (2005).

30 See Paulauskas (2005).

$31 \quad$ Jokubaitis, Lopata (2014), p. 272. 
which was attended by the heads of neighbouring states, he proclaimed: "Now, surrounded by honourable guests, I feel the same feelings, which were felt by the rulers of Lithuania in those times". ${ }^{32}$ After visiting Lutsk, which is now a Ukrainian city, Adamkus made the following entry into his diary: "This is the city of the Grand Duchy of Lithuania, here is the castle built by Liubartas, son of Gediminas, resembling Trakai castle. According to historian Alfredas Bumblauskas, I was the second ruler of Lithuania after Vytautas who visited the castle."33

Following the suggestion of Beresnevičius, the architects of Lithuania's foreign policy extended the interest sphere of the would-be regional power Lithuania far beyond the borders of the Grand Duchy. In Grand Duke Vytautas's time, the GDL reached to the Black Sea. Claiming the role of regional power for contemporary Lithuania, its government extended its zone of responsibility for spreading the values of Western civilisation to Transcaucasia, acting as one of the most vociferous advocates of Georgia, which after the Rose Revolution in Georgia in 2003 made the bid to become a member of the EU and NAто. Adamkus visited Armenia and Azerbaijan, airing Lithuania's readiness to participate in the resolution of the conflict between both countries. ${ }^{34}$

Discussing the long-term aims of small Lithuania's bid to become a regional power in Eastern Europe, Lithuanian experts refer to the prospect of finally achieving security from Russia once Lithuania will be surrounded from all sides by member states of the EU and NATO, whose new pro-Western elites will be attached to Lithuania by the ties of gratitude to Lithuania for its co-sponsorship. ${ }^{35}$ They seldom forget to add that Lithuania's bid for the role as a regional power is no threat to Russia, because the only Lithuanian interest regarding Russia is to make it safe for democracy. Do then Lithuanian politicians mean that there is no ultimate security until the democratisation of Russia?

In fact, besides this manifest agenda about Russia there may also be a hidden agenda. This agenda is grounded in the widespread persuasion in Lithuania that contemporary Russia cannot become a democratic country because it remains an empire. Any real democratisation in Russia would trigger empire-destroying centrifugal tendencies among the political forces in Russia's regions that also seek autonomy and independence. Importantly, such forces can be expected to emerge not only in its 'autonomous republics' (where

32 Cited according to Jokubaitis, Lopata (2014), p. 272.

33 Adamkus (2011), p. 312.

34 See Kojala, Ivanauskas (2014).

35 See Jonavičius (2006); Statkus, Paulauskas (2006); Baubinaitė (2011); Kasčiūnas, Kojala (2013). 
they are already present), but also in the Russian core regions. This is the main lesson which was learned by the Lithuanian political elites from Russia's two failures at democratisation in 1917 and 1991-1998.

The puzzling fact about the political geography of contemporary Lithuania is that it borders Russia not in the East, where its neighbour is Belarus, but in the West, where the Kaliningrad oblast is located, populated by nearly one million people and covering 15.100 square kilometres. Kaliningrad oblast is the part of Eastern Prussia given to the Soviet Union after the Second World War. Joseph Stalin may have toyed with the idea to merge the Soviet part of East Prussia with Soviet Lithuania, but then made it an oblast of the Russian Federation. ${ }^{36}$ Meanwhile, contemporary Lithuanians still designate these lands by the historical name of as 'Minor Lithuania', distinguishing it from 'Major Lithuania, the ethnically Lithuanian lands which were part of the GDL and then of the Russian empire. The first book in Lithuanian was printed in Königsberg in 1547, and Minor Lithuania is the place where Kristijonas Donelaitis (1714-1780) lived and worked, revered as the author of the first classic Lithuanian language poem Metai (The Seasons). Therefore Lithuanian nationalists consider the Kaliningrad oblast as part of 'historical Lithuania', suggesting that Lithuania has special rights and responsibilities for this territory. ${ }^{37}$

After the dissolution of the UssR, the Kaliningrad oblast became a distant exclave of Russia. Its high level of militarisation only increased in the postSoviet era, when many Russian military units, formerly located in the Baltic countries, were relocated to the Kalingrad oblast. Russia's demand of military transit rights was one of the most difficult issues in the Lithuanian-Russian relations since the restoration of Lithuanian independence. When Poland and Lithuania tightened the control of their borders before joining the Schengen Area, this created additional new difficulties for Russians in Kaliningrad who wanted to enter the Russian mainland. The issue of Russian military transit through Lithuania was internationalised after Lithuania's accession to NATO and the EU. It was resolved in the negotiations between Russia and the US, fostering the feeling of Lithuanian political elites of the political importance and mission of its country on the world stage.

However, many political thinkers in Lithuania, including Lopata, whose area of expertise is Kaliningrad Studies, ${ }^{38}$ consider the oblast's present status merely temporary, expecting a final resolution of the 'Kaliningrad puzzle' from the pending disintegration of Russia in the wake of its next democratic

$36 \quad$ See Safronovas (2016).

37 See Landsbergis (2003) for the most authoritative statement. See also Safronovas (2016).

38 See Lopata (2006). 
revolution. Along with democratisation, this final solution will include its demilitarisation and 'decolonisation', meaning the separation of the Kaliningrad oblast from Russia and becoming the fourth Baltic State (and another member of the EU and NATO) along with Estonia, Latvia and Lithuania. The emergence of this new state will provide a special bonus for Lithuania, because this new Baltic state is expected to gravitate to small and inoffensive Lithuania rather than to Poland and Germany, the other interested parties.

\section{$5 \quad$ Conclusion: Fruits and Predicaments of the Lithuanian 'Restoration' of the GDL}

In 2013, Lithuania used its Presidency of the Council of the European Union in 2013 as the long awaited opportunity to play the role of regional centre. One of its tasks in this role was to coordinate the completion of the negotiation process for the signing of the association agreement between Ukraine and the EU. A wave of protests called the "Euromaidan" movement was sparked by Ukraine's President Yanukovich's last minute refusal to sign this agreement at the 28-29 November 2013 EU summit in Vilnius. Thus the ongoing Ukrainian crisis started, including the violent removal of President Victor Yanukovych, the annexation of Crimea by Russia, the civil violence in Eastern Ukraine, escalating into the Russian-Ukrainian hybrid war, and the exchange of sanctions and countersanctions between the EU and Russia. Lithuania's role in this crisis remained very prominent, even after the end of its Presidency in 2014.

However, this activity peaked during the critical months until the final showdown in late February 2014. Between December 2013 and February 2014 all important Lithuanian politicians visited Kyiv, making speeches to encourage Euromaidan protesters and pressuring Ukrainian officials not to crack down on the increasingly violent demonstrators. Since Yanukovich's removal by force, Lithuania remains among the most enthusiastic supporters of the new 'pro-European' government, pleading for new sanctions against Russia and the arming of Ukraine's military with modern Western weapons, enabling it to win a military victory against the Donbass separatists and the Russian army.

A more detailed assessment of the Lithuanian contribution to the victory of the opposition is not possible without access to confidential information, which will be open only to future historians. The Lithuanian government firmly denies the allegations of the Russian mass media that Lithuanian's secret service helped train the Ukrainian activists whose violent actions played a crucial role in breaking the resistance of government forces. These allegations may be false, but the credibility of Lithuanian denials is somewhat undermined by the 
continuing refusal to admit that Lithuania (as well as Poland and Romania) from 2004 to 2006 hosted a secret US Central Intelligence Agency (CIA) prison, where terrorist suspects were detained and interrogated. The existence of such prisons has been admitted by former top officials of other suspected countries. ${ }^{39}$

While the Maidan victory was a success of Lithuania's 'neo-imperial' foreign policy, it was not an unambiguous success. Its side-effect was decreased security for Lithuania because of increased exposure to the subsequent Russian military build-up. During the last two years, Lithuania nearly doubled its military spending and re-introduced universal compulsory military service. A central topic of the Lithuanian media is the "Russian danger" and a possibly imminent military attack. The future might harbour new embarrassments, which are the topic of our concluding considerations, focusing on the contested imperial legacy of the GDL. ${ }^{40}$ One of them is related to Lithuanian-Belarusian relations.

While Lithuanian historians tell the history of the Grand Duchy as that of the predecessor of the modern Lithuanian nation state, Russian historiography describes the Grand Duchy as a Western Russian state. According to the most widespread Polish view, the Grand Duchy was at least since the late fourteenth century a part of Poland's history as an episode of its (uniquely peaceful) eastward expansion. ${ }^{41}$ The historiography of the newly independent state of Belarus is the latest participant in this contention.

Some Belarusian historians argue that the Grand Duchy was an ancient Belarusian state. According to the most radical version of this view the core of the GDL was an area called Black Rus' with its centre in Novahrudak. The region's nobility hired Baltic mercenaries to conquer neighbouring Slavonic and Baltic lands. ${ }^{42} \mathrm{~A}$ less radical version explains the emergence of the GDL in terms of a "political alliance", ${ }^{43}$ or a "symbiosis" of both ethnic groups. ${ }^{44}$ Both versions refer to the use of the Slavic language, interpreted as "old Belarusian", in the chancelery of the GDL, and claim that even if the rulers of the GDL were of non-Slavic origin, they were early and easily slavified. ${ }^{45}$ The only land to have escaped the intensified assimilation of Balts following the Belarusian conquest was Samogitia (Lower Lithuania) - the true predecessor of contemporary

\footnotetext{
39 See e.g. Open Society Foundations (2013).

40 See also Lopata, Vinogradnaitė (2016); Nikžentaitis (2016).

41 See Halecki (1919-1920); Kolankowski (1930).

42 See Ermalovič ([1989] 1991); ([1990] 2003); ([2000] 2003).

43 Kraŭcèvič ([1998] 200o), p. 141.

44 Nasevič (1993), p. 6o; Saganovič (2001), p. 71f.

45 See e.g. Saganovič (2001), p. 76.
} 
Lithuania. To avoid confusion between contemporary Lithuanians and the early Grand Duchy's metropolitan nation, which today call themselves "Belarusians" and were called Lithuanians in the Middle Ages, Belarussian historians propose that they go by different names: the latter should be called "Litvin" (литвин), the former "Lietuvis" (летувис). ${ }^{46}$

While the authoritarian regime of Alexander Lukashenko is currently suppressing nationalist zeal, one of the side-effects of a possible future democratisation of Belarus may well be a name-change for Lithuania (to "Litva") and its inhabitants (to "Litvins"). This may well spark a dispute similar to the one between Greece and the former Yugoslav republic of Macedonia ('Northern Macedonia') over its correct naming, an issue that caused a deadlock to Macedonia's accession to the NATO and EU for so long. Additionally, the coming conflict over which country is 'the true Lithuania' also implies the resurrection of the "Vilnius question", which poisoned Polish-Lithuanian relations during the interwar period. The famous British historian Norman Davies accepted the Belarusian view of the Grand Duchy's history, expounding it in his bestseller Vanished Kingdoms. ${ }^{47}$ Davies was furiously denounced by Lithuania-based authors as a result. ${ }^{48}$

Another potential embarrassment involves Polish-Lithuanian relations. How can the breath-taking programme of the restoration of the GDL or making Lithuania a "regional centre" be harmonised with similar aspirations of Poland? Nearly all monuments of Western European architecture in the territory of contemporary Belarus and Ukraine, claimed as vestiges of a 'Greater Lithuania' in carefully documented, richly illustrated and widely sold books, ${ }^{49}$ can be - and are - also claimed by Polish patriots as monuments of 'Greater Poland'. Importantly, the Polish legacy in the former PLC is represented in Belarus, Lithuania and Ukraine by large, well organised and politically active Polish minorities, which work to preserve this legacy and foster the relations with the homeland. Differently from Poland, contemporary Lithuania has no such powerful agency to assert its influence in the former GDL lands.

There are influential political forces in contemporary Poland pleading for the resuscitation of Józef Piłsudski's interwar political project of Intermarium (Międzymorze) - a Poland-led federation, including not only new states on the territory of the former PLC, but also nearly all countries of post-communist

46 See Kraŭcèvič (2003). For the response of Lithuanian historians see Bumblauskas (2008).

47 See Davies (2012), pp. 229-308.

48 Baronas, Rowell (2015), p. 77.

49 See Bumblauskas (2005); Valionytė (2009); Valionytė (2009-2012). 
"new Europe". ${ }^{50}$ There is no clarity about its relationship to the existing EU. After the further eastern expansion of the EU, including not only Ukraine, but also Belarus, Intermarium may act as the bloc of nearly all new Eastern EU members, united not only against the resurrection of Russian imperialism, but also against German hegemony in the EU. However, it may also be conceived as an alternative to the EU, especially for the emergency case of its dissolution.

In Lithuania, $6.6 \%$ of its total population identify as Polish. This group is politically represented by the Electoral Action of Poles in Lithuania - Christian Families Alliance (EAPL-CFA), which won 8 seats (from a total of 141) in the election of the Lithuanian parliament in October 2016. Lithuania may aspire to play the role of regional centre, but the inadequacy of its real resources for this aim is displayed every time when it is censured by Poland's government for violations of Polish minority rights. Although the situation of the Polish minority in Lithuania is demonstrably the best among all former Commonwealth lands, ${ }^{51}$ varying Polish political forces harshly criticise Lithuania for what they perceive as infraction of the Polish minority rights by Lithuanian government. ${ }^{52}$

National identities and stereotypes continue in force in the enlarging European Union, influencing the foreign policy of its new members such as Luthuania, the case analysed here. The analysis demonstrates that accession to the EU or NATO does neither end independent foreign policy-making nor liberates it from the influence of nationalist myths and legacies. Quite the opposite: $\mathrm{EU}$ membership may be used by national political elites as a source of opportunities in the pursuit of their particular (and sometimes murky) agendas.

\section{Bibliography}

Adamkus, Valdas (2004a). 'Lithuania as a Centre of Regional Cooperation', Lithuanian Foreign Policy Review, 13-14, pp. 17-20.

Adamkus, Valdas (2004b). Respublikos Prezidento Valdo Adamkaus kalba Lietuvos diplomatinių misijų vadovams, 13.07.2004. Address by H. E. Mr. Valdas Adamkus, President of the Republic of Lithuania, during the meeting of the heads of foreign diplomatic missions in Lithuania. http://archyvas.lrp.lt/lt/news.full/5121 [accessed 27.04.2019].

$50 \quad$ See e.g. Chodakiewicz (2012); Łukasiewicz (2010).

$5^{1} \quad$ See e.g. Motuzas (2001).

$5^{2} \quad$ See Tracevskis (2016). 
Adamkus, Valdas (2005). 'Black Sea Vision', Lithuanian Foreign Policy Review, 15-16, pp. 7-11.

Adamkus, Valdas (2011). Paskutine kadencija. Prezidento dienoraščiai (Vilnius: Tyto alba).

Baronas, Darius, Artūras Dubonis, Rimvydas Petrauskas (2011). XIII a. - 1385 m. Valstybès iškilimas tarp Rytu ir Vakaru. Lietuvos istorija, t. 3 (Vilnius: Baltos lankos).

Baronas, Darius, Stephen C. Rowell (2015). The Conversion of Lithuania. From Pagan Barbarians to Late Medieval Christians (Vilnius: The Institute of Lithuanian Literature and Folklore).

Baubinaite, Kristina (2011). 'The Preconditions of the Grand Strategy in Lithuania', Lithuanian Foreign Policy Review, 26, pp. 54-83.

Beresnevičius, Gintaras (1990). Dausos. Pomirtinio gyvenimo samprata senojoje lietuviu pasaulèžiūroje (Klaipèda: Gimtinè).

Beresnevičius, Gintaras (1995). Baltų religinès reformos (Vilnius: Taura).

Beresnevičius, Gintaras (1998). Kosmosas ir šventvietès lietuviu ir prūsu religijose (Kaunas: vdu leidykla).

Beresnevičius, Gintaras (2002). Ant laiko ašmenų (Vilnius: Aidai).

Beresnevičius, Gintaras (2003a). Imperijos darymas. Lietuviškos ideologijos metmenys. Europos Sajunga ir Lietuvos geopolitika XXI a. pirmojoje pusejje (Vilnius: Vilniaus universitetas, Tarptautinių santykių ir politikos mokslų institutas).

Beresnevičius, Gintaras (2003b). Palemono mazgas. Palemono legendos periferinis turinys. Religinè istorinè studija (Vilnius: Sapnų sala).

Beresnevičius, Gintaras (2004). Lietuviu religija ir mitologija. Sisteminè studija (Vilnius: Tyto alba).

Bumblauskas, Alfredas (2005). Senosios Lietuvos istorija 1009-1795 (Vilnius: R. Paknio leidykla).

Bumblauskas, Alfredas (2008). 'LDK paveldo dalybos ir "Litva-Letuva" distinkcijos konceptas', in Alfreda Bumblauskas, Šarūnas Liekis, Grigorijus Potašenko (eds), Lietuvos Didžiosios Kunigaikštijos tradicija ir paveldo 'dalybos'(Vilnius: vu leidykla), pp. $15^{-66 .}$

Chodakiewicz, Marek Jan (2012). Intermarium. The Land between the Black and Baltic Seas (New Brunswick, NJ: Transaction Publishers).

Davies, Norman (2012). Vanished Kingdoms. The Rise and Fall of States and Nations (New York: Penguin Books).

Dundzila, Vilius Rudra, Michael Strmiska (2005). 'Romuva. Lithuanian Paganism in Lithuania and America' in Michael F. Strmiska (ed.) Modern Paganism in World Cultures. Comparative Perspectives (Santa Barbara: ABC-CLIO), pp. 241-298.

Eder, Klaus (2009). 'A Theory of Collective Identity. Making Sense of the Debate on a European Identity', European Journal of Social Theory, 12.4, pp. 427-447.

Ermalovič, Mikola I. ([1989] 1991). Pa sljadax adnago mifa (Minsk: Navuka I tėxnika). 
Ermalovič, Mikola I. ([1990] 2003). Staražytnaja Belarus'. polacki i novagarodski peryjady. 2-e vyd. (Minsk: Mastackaja litaratura).

Ermalovič, Mikola I. ([2000] 2003). Belaruskaja dzjaržava Vjalikae Knjastva Litoŭskae (Minsk: Bellitfond).

Gedgaudas, Česlovas (1972). Mūsų praeities beieškant (Mexico: Č. Gedgaudas).

Genys, Dainius (2011). Lietuvos pilietinès visuomenès ribos ir konfliktai dèl jų. Doctoral dissertation (Kaunas: Vytautas Magnus University).

Gudavičius, Edvardas (1999). Lietuvos istorija nuo seniausių laiku iki 1569 metu (Vilnius: Lietuvos rašytojų s-gos leidykla).

Halecki, Oskar (1919-1920). Dzieje Unii Jagiellońskiej. T. 1-2 (Krakow: Akad. Umiejętności Fundusz N. Bucewicza).

Hroch, Miroslav (1985). Social Preconditions of National Revival in Europe. A Comparative Analysis of the Social Composition of Patriotic Groups among the Smaller European Nations (Cambridge: Cambridge University Press).

Jokubaitis, Alvydas, Raimundas Lopata (2014). Lietuva kaip problema. Filosofiniai istoriniai politikos tyrinejjimai (Vilnius: Tyto alba).

Jonavičius, Laurynas (2006). 'Geopolitical Projections of New Lithuanian Foreign Policy', Lithuanian Foreign Policy Review, 17, pp.15-40.

Kasčiūnas, Laurynas, Linas Kojala (2013). 'EU Policy towards Russia. Will We Fill the Strategic Vacuum?', Lithuanian Foreign Policy Review, 30, pp. 133-142.

Kiaupa, Zigmantas, Jūratė Kiaupienė, Albinas Kuncevičius (2000). The History of Lithuania before 1795 (Vilnius: Lithuanian Institute of History).

Kiaupienė, Jūratė, Rimvydas Petrauskas (2009). Nauji horizontai. Dinastija, visuomenè, valstybè. Lietuvos Didžioji Kunigaikštystè 1386-1529 m. Lietuvos istorija, t. 4. (Vilnius: Baltos lankos).

Kolankowski, Ludwik (1936). Polska Jagiellonów. Dzieje polityczne (Lwów: Skład głowny w Księgarni Gubrynowicz i syn).

Kraŭcėvič, Aljaksandr ([1998] 200o). Stvarènne Vjalikaga Knjastva Litoŭskaga (Rzeszów: Uniwersytet Marii Curie-Skłodowskiej w Lublinie).

Kraŭcèvič, Aljaksandr (2003). 'Terminy Litva i Letuva u sučasnaj belauskaj gistaryjagrafii', Gistaryčny al'manakh 9, pp. 104-107.

Kojala, Linas, Vilius Ivanauskas (2014). 'Lithuanian Eastern Policy 2004-2014. The Role Theory Approach', Lithuanian Foreign Policy Review, 32, pp. 49-72.

Landsbergis, Vytautas (2003). Karaliaučius ir Lietuva. Nuostatos ir idëjos (Vilnius: Demokratinès politikos institutas).

Lèka, Aušra. (2015). 'Lietuvos (už)valdymas: režisieriai, prodiuseriai, aktoriai', Veidas tag archive. http://www.veidas.lt/tag/albinas-januska [accessed 27.04.2019].

Lopata, Raimundas (2006). Anatomy of a Hostage. Kaliningrad Anniversary Case (Tartu: Baltic Defence College). 
Lopata, Raimundas (2010). Politikai ir istorija. Algirdo Brazausko ir Vytauto Landsbergio istorijos sampratos (Vilnius: vu leidykla).

Lopata, Raimundas, Nortautas Statkus (2005). 'Empires, the World Order and Small States', Lithuanian Foreign Policy Review, 15-16, pp. 16-5o.

Lopata, Raimundas Inga Vinogradnaitė (2016). Lietuvos ir Baltarusijos istorijos politika (Vilnius: vu leidykla).

Łukasiewicz, Sławomir (2010). Trzecia Europa. Polska myśl federalistyczna w Stanach Zjednoczonych, 1940-1971 (Warsaw: Institute for National Remembrance).

Motuzas, Remigijus (2001). 'Education of National Minorities in Lithuania', Lithuanian Foreign Policy Review, 7, pp. 1-12.

Nasevič, Vjačaslaŭ L. (1993). Pačatki Vjalikaga knjastva Litoŭskaga. Padzei i asoby. (Minsk: Polymja).

Norkus, Zenonas (2012). On Baltic Slovenia and Adriatic Lithuania. A Qualitative Comparative Analysis of Patterns in Post-Communist Transformation (Budapest: CEU Press).

Norkus, Zenonas (2018). An Unproclaimed Empire. The Grand Duchy of Lithuania From the Viewpoint of Comparative Historical Sociology of Empires (Abingdon: Routledge).

Open Society Foundations (2013). 'Lithuania's Silence on CIA Abuses Faces European Court Challenge'. https://www.opensocietyfoundations.org/press-releases/ lithuanias-silence-cia-abuses-faces-european-court-challenge [accessed 27.04.2019].

Paulauskas, Kęstutis (2005). 'The Baltic States. Picking Regions, Shedding Myths, Decoding Acronyms', Lithuanian Foreign Policy Review, 15-16, pp. 51-64.

Pranskevičiūtė Rasa, Eglè Aleknaitė (2014). ‘Šiuolaikinė pagonybė Lietuvoje. Matomos ir nematomos grupès', in Milda Ališauskienè (ed.) Religijų ivvairove Lietuvoje: portretai, kasdienybe ir šventès (Vilnius: Versus aureus), pp. 170-173.

Rowell, Stephen C. (1994). Lithuania Ascending. A Pagan Empire Within East-Central Europe, 1295-1345 (Cambridge: Cambridge University Press).

Nikžentaitis, Alvydas (2016). 'Abiejų Tautų Respublikos ir Lietuvos Didžiosios Kunigaikštystės praeitis lietuvių, lenkų, baltarusių ir ukrainiečių atminties kultūroje po 1990 metų', Lietuvos istorijos metraštis, 1, pp. 49-70.

Paulauskas, Artūras (2004). 'Lithuania's New Foreign Policy', Lithuanian Foreign Policy Review, 13-14, pp. 7-16.

Safronovas, Vasilijus (2016). The Creation of National Spaces in a Pluricultural Region. The Case of Prussian Lithuania (Boston: Academic Studies Press).

Saganovič, Genadz' (2001). Narys gistoryi Belarusi ad staražytnasci da kanca XVIII stagoddzja. (Minsk: Encyklapedyks).

Statkus, Nortautas, Kęstutis Paulauskas (2006). 'Foreign Policy of Lithuania. Linking Theory to Practice', Lithuanian Foreign Policy Review, 17, pp.41-82.

Statkutė de Rosales, Jūratė (2004). Balts and Goths. The Missing Link in European History. (Lemont [Ill.]: Vydūnas Youth Fund). 
Tracevskis, Rokas (2016). 'Lietuva savo suvereniteto Lenkijai perduoti neprivalo', o7.12.2016. http://www.delfi.lt/news/ringas/lit/r-tracevskis-lietuva-savo-suvereniteto-lenkijaiperduoti-neprivalo.d?id=72984206 [accessed 27.04.2019].

Valionis, Antanas (2006). 'Lithuania's New Foreign Policy Agenda', Lithuanian Foreign Policy Review, 17, pp. 6-14.

Valionytė, Birutė (2009). Reikšmingas LDK paveldas Baltarusijoje / Significant Heritage of the Grand Duchy of Lithuania in Belarus (Vilnius: Artlora).

Valionytė, Birutė (2009-2012). Didžioji Lietuva. Vol. 1-3 (Vilnius: Artlora). 